\title{
Summer temperature trend over the past two millennia using air content in Himalayan ice
}

\author{
S. Hou ${ }^{1,2,3}$, J. Chappellaz ${ }^{1}$, J. Jouzel ${ }^{2}$, P. C. Chu ${ }^{4}$, V. Masson-Delmotte ${ }^{2}$, D. Qin $^{3}$, D. Raynaud ${ }^{1}$, P. A. Mayewski ${ }^{5}$, \\ V. Y. Lipenkov ${ }^{6}$, and S. Kang ${ }^{3}$ \\ ${ }^{1}$ Lab. de Glaciologie et Geophysique de l'Environnement (CNRS-UJF), 54 rue Molière, Domaine Univ., BP 96, 38402 St \\ Martin d'Hères, France \\ ${ }^{2}$ IPSL-Lab. des Sciences du Climat et de l'Environnement (CEA-CNRS-UVSQ), CE Saclay, Annexe Orme des Merisiers, \\ 91191 Gif-sur-Yvette, France \\ ${ }^{3}$ Lab. of Cryosphere and Environment, Chinese Academy of Sciences, 260 Donggang West Road, 730000 Lanzhou, China \\ ${ }^{4}$ Naval Ocean-Atmosphere Prediction Lab., Dept. of Oceanography, Naval Postgraduate School, Monterey, CA 93943, USA \\ ${ }^{5}$ Climate Change Institute (CCI), Univ. of Maine, Orono, ME 04469, USA \\ ${ }^{6}$ Arctic and Antarctic Research Institute, Beringa Street 38, 199397, St. Petersburg, Russia
}

Received: 18 July 2005 - Published in Clim. Past Discuss.: 22 September 2005

Revised: 27 November 2006 - Accepted: 10 January 2007 - Published: 7 February 2007

\begin{abstract}
Two Himalayan ice cores display a factor-two decreasing trend of air content over the past two millennia, in contrast to the relatively stable values in Greenland and Antarctica ice cores over the same period. Because the air content can be related with the relative frequency and intensity of melt phenomena, its variations along the Himalayan ice cores provide an indication of summer temperature trend. Our reconstruction point toward an unprecedented warming trend in the 20th century but does not depict the usual trends associated with "Medieval Warm Period" (MWP), or "Little Ice Age" (LIA).
\end{abstract}

\section{Introduction}

Relatively little is known concerning climatic change over the Himalayas and Tibetan Plateau for time scales ranging from centuries to thousands of years. This is largely due to the sparsity of meteorological stations and its unique topographic setting. The longest instrumental records from the region date back only to AD1935. Ice cores collected from high elevation glaciers in the Himalayas provided extended records of past climate in the region (Thompson et al., 2000; Kang et al., 2002; Qin et al., 2002).

Ice water stable isotopes $\left(\delta^{18} \mathrm{O}\right.$ and $\left.\delta \mathrm{D}\right)$ are the usual proxy for air temperature but many other factors may affect them such as atmospheric circulation, moisture transport, and variability of precipitation (Hoffmann and Heimann, 1997;

Correspondence to: $\mathrm{S}$. Hou

(shugui@lzb.ac.cn)
Araguás-Araguás et al., 1998). For instance, the millennial $\delta^{18} \mathrm{O}$ record of the Dasuopu ice cores suggests a significant 20th century warming (Thompson et al., 2000) and existence of LIA (Yao et al., 2002). However, paleolimnological studies in the Khumbu valley (Fig. 1) indicate a cold phase during MWP (Lami et al., 1998), and no 20th century $\delta^{18} \mathrm{O}$ enrichment was found from an $80 \mathrm{~m}$ ice core recovered in 1998 from the East Rongbuk (ER) Glacier $\left(28^{\circ} 01^{\prime} \mathrm{N}, 86^{\circ} 58^{\prime} \mathrm{E}\right.$, $6450 \mathrm{~m}$ above sea level, Fig. 1) (Qin et al., 2002). Instead, the ER ice core $\delta^{18} \mathrm{O}$ record is significantly and inversely correlated to the Southwest Indian Monsoon intensity (Qin et al., 2002; Zhang et al., 2005), suggesting the dominance of a "precipitation amount effect" on stable isotopes (Hoffmann and Heimann, 1997; Araguás-Araguás et al., 1998). Here we present a novel attempt to reconstruct the summer temperature trend using a physical proxy, the ice core gas content, that reflects relative frequency and intensity of melt phenomena, thus providing valuable data on past summer climate (Herron et al., 1981).

\section{Experimental methods}

We recovered one ice core to bedrock in 2001 (117.06 m deep, hereafter "Core 2001"), and two cores in 2002 (108.83 m deep, hereafter "Core 2002", and $95.80 \mathrm{~m}$ deep, respectively) on the col of the ER Glacier at $6518 \mathrm{~m}$ above sea level (Fig. 1) using an electromechanical drill in a dry hole. A repeating survey with a Sokkia GSS1A Global Positioning System (accuracies of $\pm 5 \mathrm{~mm}$ over distance up to $10 \mathrm{~km}$ ) in 1998 and 2002 did not identify horizontal movement at

Published by Copernicus GmbH on behalf of the European Geosciences Union. 

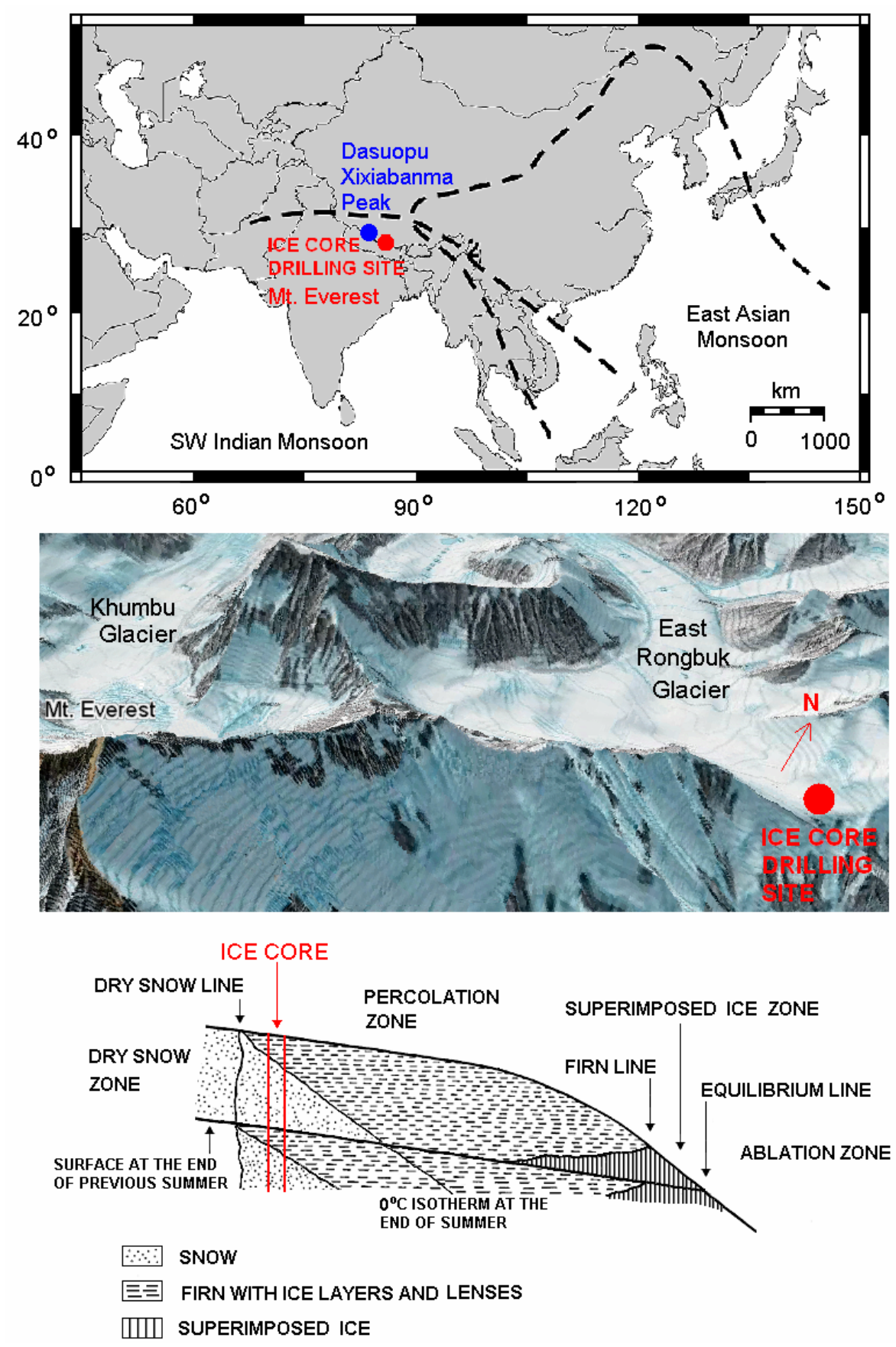

Fig. 1. Location map of ice core drilling sites, together with a sketch of thermal zones on the glacier.

the drill site. Ice layers are horizontal in the cores, suggesting negligible ice dynamical deformation. The average annual net accumulation is $\sim 400 \mathrm{~mm}$ water equivalent as determined by snow pits and the $80 \mathrm{~m}$ ice core studies (Hou et al., 2002). Bore-hole temperatures in the $108.83 \mathrm{~m}$ core ranged from a minimum of $-9.6^{\circ}$ at $20 \mathrm{~m}$ to $-8.9^{\circ}$ at the bottom. We maintained the temperature of the cores below $-5^{\circ}$ from the time of drilling until analysis.
Seventy-seven samples from Core 2001, and 123 from Core 2002 were measured for air content after extracting the air by melting and refreezing the ice under vacuum, and chromatographic measurement of the air peak with a precision within $\pm 5 \%$ (method a). All samples were selected below the close-off depth $(28.2 \mathrm{~m}$ for Core 2001 and $26.2 \mathrm{~m}$ for Core 2002, respectively) down to the bottom part of the cores. Each sample ( $\sim 50 \mathrm{~g})$ corresponds to $4-10 \mathrm{~cm}$ ice core 
intervals covering seasonal for the upper core sections to multi-annual for the bottom sections. Additionally, we measured 4 samples from Core 2001 by an accurate air pressure method in a calibrated volume that has a proven accuracy within $\pm 0.6 \%$ (method b) (Lipenkov et al., 1995). The ER results with method $\mathrm{b}$ are in good agreement with chromatographic measurements (Fig. 2). For consistency, we only include the measurements by method a for further discussion.

Gas content measurement implies that a portion of air is lost by cut-bubbles at the sample surface. As the shallower samples include bigger bubbles, the cut-bubble effect could generate an underestimate of the air content in shallower samples compared with deeper samples. To account for this effect, we measured the average bubble size of six samples taken at different depths between 26.4 and $115 \mathrm{~m}$. We then calculated the cut-bubble correction coefficient, ranging from $2 \%$ in the deepest section to $14 \%$ at $26 \mathrm{~m}$. We corrected all measured air contents as a function of depth with a thirdorder polynomial regression running through the six measured correction coefficients $\left(\mathrm{R}^{2}=0.9989\right)$.

\section{Dating}

We dated the ice core gas age by a combination of methane and $\delta^{18} \mathrm{O}_{\text {atm }}$ records with comparison to the GRIP chronology (Hou et al., 2004). We estimate a gas-ice age difference of around 30 years based on the ice core bore hole gas measurements at the Dasuopu glacier, Himalaya (Xu and Yao, 2001), and calculation from the present accumulation rate and temperature (Schwander et al., 1997). The final ice age is consistent with the age-depth function of an $80 \mathrm{~m}$ annually dated ice core recovered from the same glacier (Kang et al., 2002; Qin et al., 2002). We estimate a dating error \pm 10 years throughout the whole ice cores.

\section{Factors controlling gas content}

In absence of melting, the air content of the ice $\left(V\right.$, in $\mathrm{cm}^{3} / \mathrm{g}$ of ice) depends on the pore volume $\left(V_{c}\right)$, the air pressure $\left(P_{c}\right)$ and temperature $\left(T_{c}\right)$ prevailing at the close-off depth interval (Martinerie et al., 1992) as:

$V=V_{c} \frac{P_{c}}{T_{c}} \frac{T_{o}}{P_{o}}$

where $P_{o}$ and $T_{o}$ are the standard pressure $(1013 \mathrm{mb})$ and temperature $\left(273^{\circ} \mathrm{K}\right)$, respectively; $V_{c}$ is the pore specific volume of ice at close-off $\left(\mathrm{cm}^{3} / \mathrm{g}\right)$.

With the present conditions at our drill site $\left(P_{c}=462 \mathrm{mb}\right.$; $\left.T_{c}=264 \mathrm{~K}\right)$, and the empirical dependence of $V_{c}$ on temperature (Martinerie et al., 1992), $V$ is calculated as $0.066 \mathrm{~cm}^{3} / \mathrm{g}$ using Eq. (1). This is roughly twice the average measured $V$ values (Fig. 2). Thus other processes during snow transformation contribute to the low gas content of our cores rather than those identified for the dry snow zone of polar regions
(Martinerie et al., 1992; Delmotte et al., 1999, and references therein).

On our site, an ice core annual layer (Fig. 1) consists of alternating summer percolation and winter dry snow strata. In summer, snow melting can percolate downwards $\left(0^{\circ}\right.$ isotherm at the end of summer; Fig. 1) (Paterson, 1994). This accelerates and strengthens packing by lubricating the grains. Refreezing of melt-water also speeds up the later stages of snow transformation. As a portion of air spaces is filled with water (Paterson, 1994), $V_{c}$ in Eq. (1) is reduced, resulting in low gas content in the summer stratum.

Energy and mass exchange experiments carried out on Himalayan and Andean glaciers suggest that snow/ice melting is essentially driven by the short-wave radiation balance (Aizen et al., 2002; Wagnon et al., 1999). During the dry season, the negative latent heat flux generates a strong sublimation which maintains the glacier surface cold. During the wet season, the reduced short-wave radiation due to higher cloudiness does not compensate for the increased long-wave radiation. Increased atmospheric humidity leads to a reduced humidity gradient between the snow surface and the atmosphere. Thus the incoming energy generates melting instead of sublimation.

Because on our site the period with highest humidity coincides with the highest temperature, both phenomena add on to generate melting. Observations on the Xixibangma glacier points toward a very good correlation between snow/ice melt and air temperature, and radiation due to melting accounts for up to $86 \%$ of incoming energy (Aizen et al., 2002). Thus we interpret the gas content as primarily an index of summer warmth.

We measured a section of Core 2002 in the range $34.42 \mathrm{~m}$ to $35.27 \mathrm{~m}$, where the summer and winter strata can be distinguished by seasonality of major ions (Qin et al., 2002; Kang et al., 2002, and unpublished data; Fig. 2). The comparatively low gas content of the summer strata validates the connection of gas content with summer temperature. Winter layers also show depleted air content because they are probably affected by water percolation during the next summer as well.

From Eq. (1), the air content is also affected by changes of air temperature and atmospheric pressure (i.e., elevation). Keeping other factors unchanged under present conditions, a $\pm 2^{\circ}$ change of $T_{c}$ results in a change of $V$ of $\pm 0.0005 \mathrm{~cm}^{3} / \mathrm{g}$, i.e., only $\sim 2 \%$ of the observed $V$ variations along our profiles. Persistent retreat of the glacier terminal moraines is evident for both slopes of Mt. Everest throughout the late Holocene (Richards et al., 2000; Zheng et al., 2002). Consequently, we expect a progressive thinning at the drill site (i.e., increasing air pressure), which would increase, rather than decrease air content over time as we observe. In conclusion, we expect that our air content record is mainly connected with the magnitude and frequency of snow melting on the glacier surface. 


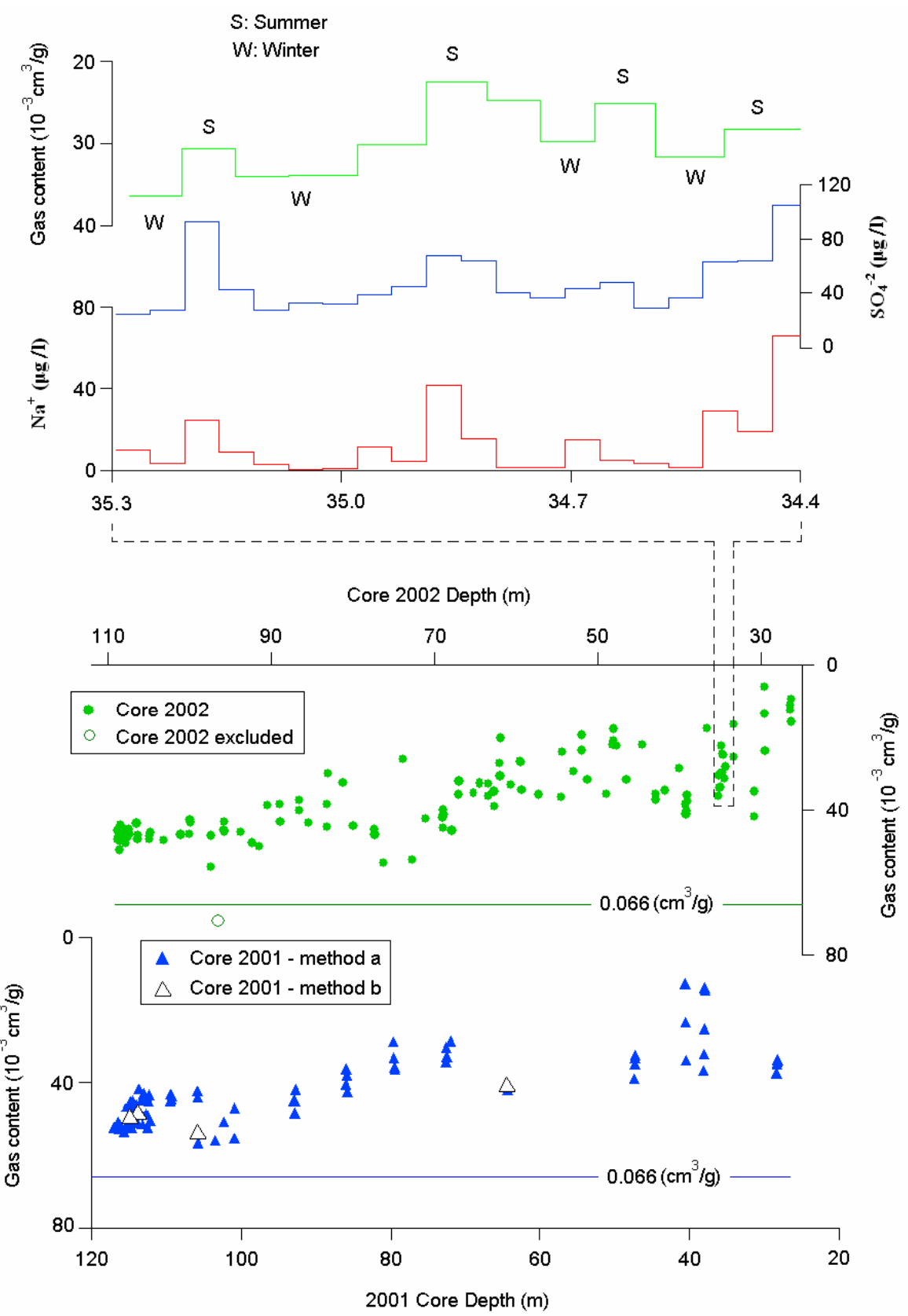

Fig. 2. Air content profiles of Cores 2001 and 2002, together with $\mathrm{SO}_{4}^{2-}$ and $\mathrm{Na}^{+}$profiles identifying summer and winter strata in the detailed section. The sample "Core 2002 excluded" may represent an extreme low temperature period without any surface snow melting, and we exclude it for further consideration.

\section{Summer temperature trend}

We combined the corrected gas content records of Cores 2001 and 2002 into one time sequence due to their similar features (Fig. 2), thus leading to a better time resolution. Both cores reveal a large decrease of air content over the last two millennia from mean values $\sim 0.050 \mathrm{~cm}^{3} / \mathrm{g}$ to $\sim 0.028 \mathrm{~cm}^{3} / \mathrm{g}$. Most of the decrease takes place over the last 200-300 years. Air content decreases in parallel with a larger deviation around the mean value, which may reflect the thinning of annual layers with depth, as shallower samples partly depicting the seasonal variability of air content (Fig. 3a) whereas the deepest samples integrating this variability through multi-annual depth resolution.

The gas content profile (Fig. 3b) thus suggests unprecedented warm summer temperatures at the altitude of our drill site for the 20th century. A comparable warming trend 


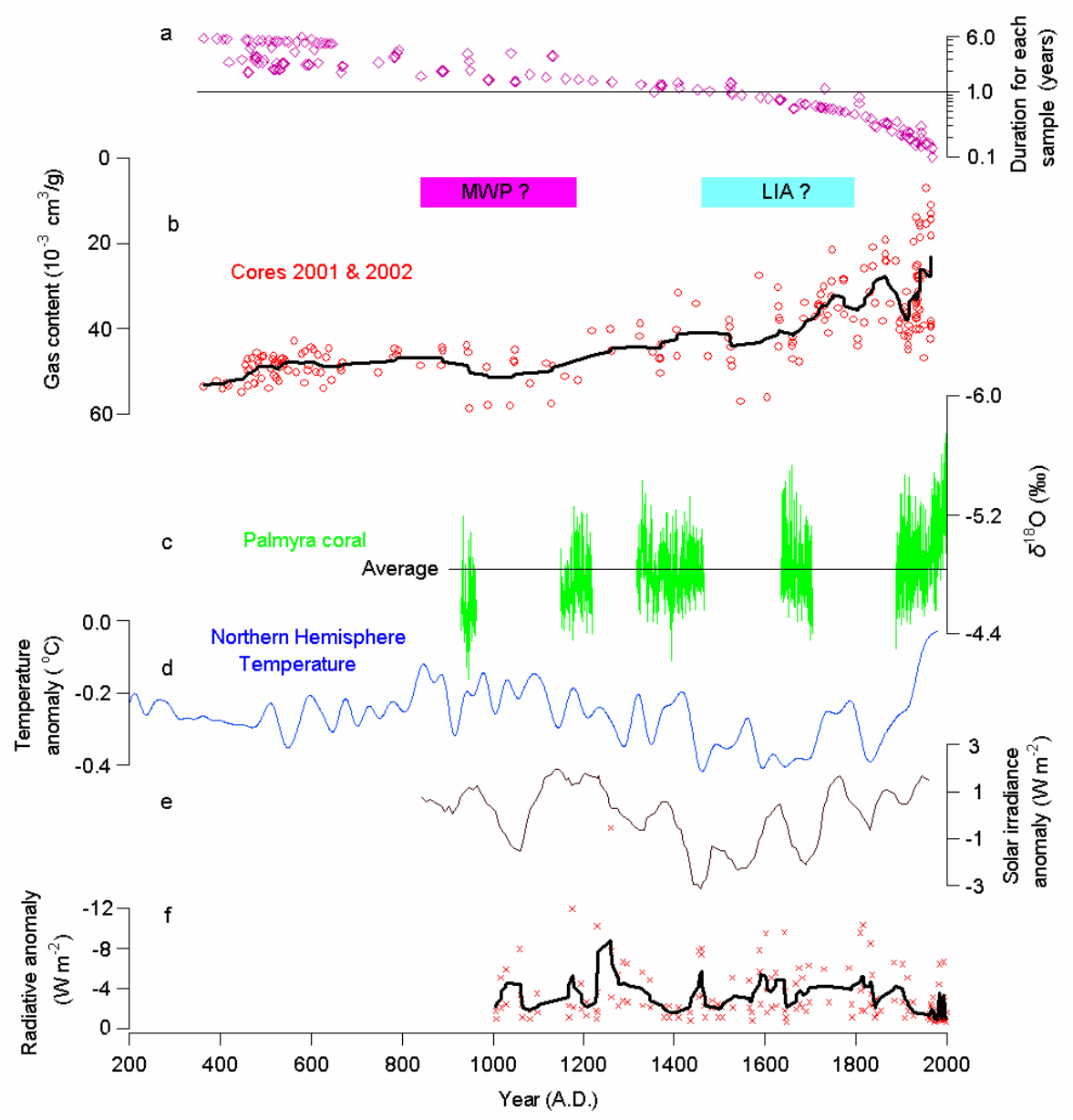

Fig. 3. (a) Average age representativity of each sample. (b) Gas content time series, with a binomial smoothing trend (thick black line). Note that the gas content is plotted as a function of the age of ice, because in this case it is affected by surface processes. (c) The monthly resolved Palmyra coral $\delta^{18} \mathrm{O}$ records. The black horizon represents the average of all the coral dataset. (d) Temperature reconstruction of North Hemisphere. (e) Reconstruction of solar irradiance anomalies. (f) Radiative forcing associated with volcanic eruptions recorded in ice cores, with a binomial smoothing trend (thick black line). The approximate timing and duration of the "Little Ice Age" (LIA) and the "Medieval Warm Period" (MWP) are marked by horizontal bars.

was also identified in the Himalayas using meteorological data (Liu and Chen, 2000), dendroclimatic signals from the Nepalese Himalayas (Cook et al., 2003) and western central Asia (Esper et al., 2002a). However, there is no clear evidence in our record of other climatic events such as the "Little Ice Age" (LIA) or the "Medieval Warm Period" (MWP), thus it does not reinforce the trends based on the reconstruction of Northern Hemisphere temperature for the past two millennia (Fig. 3d; Mann and Jones, 2003), or the dendroclimatic signal from the Northern Hemisphere extratropics (Esper et al., 2002b). On the other hand, a palaeoclimate reconstruction based on pigment and diatom assemblage variations from two lakes of the Khumbu valley (Fig. 1) indicates warm phase during the 13-16th centuries and cold phase during the 5-12th centuries (Lami et al., 1998). The relatively lower temperature before the 12th century is consistent with the general advance of Himalayan glaciers during the 5-6th and 9-12th centuries (Röthlisberger and Geyh, 1985). The recent coral reconstruction from Palmyra Island in the central tropical Pacific also supports a cool MWP and a warm LIA (Fig. 3c; Cobb et al., 2003), which indeed better fit with the trend from our gas content record.

Though decadal to centennial climate variability during the pre-industrial appears to have been dominated by solar and, to a less extent, volcanic forcing (Shindell et al., 2003), connection between our signal and solar (Fig. 3e; Bard et al., 2000) or volcanic (Fig. 3f; Crowley, 2000) activity variations for the past millennium is unclear. The primary impact of solar activity on climate is to change thermal gradients rather than direct solar heating. This means that the high and perhaps mid-latitudes could be out-of-phase in temperature with the low latitudes because of displacement of heat via changes 
in atmospheric and oceanic thermohaline circulation (Goosse et al., 2004). The resemblance of our summer temperature reconstruction (Fig. 3b) and the tropical Pacific corals (Fig. 3c) during MWP and LIA might reflect interaction between the El Niño -Southern Oscillation (ENSO) and the Asian Monsoon (Charles et al., 1997). The mechanisms causing such variability may involve the large-scale atmospheric circulation encompassing the Pacific and Indian Ocean monsoon areas. Our climatic signal suggests that such a spatial pattern might exist before the involvement of modern human activities in the tropical climate system.

\section{Conclusions}

Though a quantitative calibration to temperature is unavailable due to lack of ad hoc meteorological data, coarse sampling resolution and uncertainty of ice core dating, our gas content reconstructions highlight an unprecedented warming trend in the 20th century compared with the last two millennia. Moreover, it suggests that Himalayan climate might be out of phase with extratropical climate on centennial scale, highlighting the complexity of climatic change in the tropic.

Acknowledgements. Thanks are due to D. Zhang and other scientists, technicians, graduates and porters for their hard work in the field, to B. Bellier, A. Landais, N. Caillon, S. Cherrier for their help in the laboratories at LSCE and LGGE. This work was supported by the Natural Science Foundation of China (90411003; 40205007), the Chinese Academy of Sciences, the French-Chinese PICS "CLEAH" of CNRS (Service des Relations Internationales), the French embassy in China, and the US National Science Foundation.

Edited by: E. Brook

\section{References}

Aizen, V. B., Aizen, E. M., and Nikitinb, S. A.: Glacier regime on the northern slope of the Himalaya (Xixibangma glaciers), Quat. Int., 97-98, 27-39, 2002.

Araguás-Araguás, L., Froehlich, K., and Rozanski, K.: Stable isotope composition of precipitation over southeast Asia, J. Geophys. Res., 103(D22), 28 721-28 742, 1998.

Bard, E., Raisbeck, G., Yiou, F., and Jouzel, J.: Solar irradiance during the last 1200 years based on cosmogenic nuclides, Tellus, B52(3), 985-992, 2000.

Charles, C. D., Hunter, D. E., and Fairbanks, R. G.: Interaction between the ENSO and the Asian Monsoon in a coral record of tropical climate, Science, 277, 925-928, 1997.

Cobb, K. M., Charles, C. D., Cheng, H., and Edwards, R. L.: El Niño/Southern Oscillation and tropical Pacific climate during the last millennium, Nature, 424, 271-276, 2003.

Cook, E. R., Krusic, P. J., and Jones, P. D.: Dendroclimatic Signals in Long Tree-Ring Chronologies from the Himalayas of Nepal, Int. J. Climatol., 23, 707-732, 2003.

Crowley, T. J.: Causes of climate change over the past 1000 years, Science, 289, 270-277, 2000.
Delmotte, M., Raynaud, D., Morgan, V., and Jouzel, J.: Climatic and glaciological information inferred from air-content measurements of a Law Dome (East Antarctica) ice core, J. Glaciol., 45(150), 255-263, 1999.

Esper, J., Schweingruber, F. H., and Winiger, M.: 1300 years of climatic history for Western Central Asia inferred from tree-rings, Holocene, 12, 267-277, 2002a.

Esper, J., Cook, E. R., and Schweingruber, F. H.: Low-frequency signals in long tree-ring chronologies for reconstructing past temperature variability, Science, 295, 2250-2253, $2002 \mathrm{~b}$.

Goosse, H., Masson-Delmotte, V., Renssen, H., Delmotte, M., Fichefet, T., Morgan, V., van Ommen, T., Khim, B. K., and Stenni, B.: A late medieval warm period in the Southern Ocean as a delayed response to external forcing? Geophys. Res. Lett., 31, L06203, doi:10.1029/2003GL019140, 2004.

Herron, M. M., Herron, S. L., and Langway Jr., C. C.: Climatic signal of ice melt features in southern Greenland, Nature, 293(5831), 389-391, 1981.

Hoffmann, G. and Heimann, M.: Water isotope modeling in the Asian monsoon region, Quat. Int., 37, 115-128, 1997.

Hou, S., Qin, D., Yao, T., Zhang, D., and Chen, T.: Recent change of the ice core accumulation rates on the Qinghai-Tibetan Plateau, Chin. Sci. Bull., 47(20), 1746-1749, 2002.

Hou, S., Qin, D., Jouzel, J., Masson-Delmotte, V., von Grafenstein, U., Landais, A., Caillon, N., and Chappellaz, J.: Age of Himalayan bottom ice cores, J. Glaciol., 50(170), 467-468, 2004.

Kang, S., Mayewski, P. A., Qin, D., Yan, Y., Zhang, D., Hou, S., and Ren, J.: Twentieth century increase of atmospheric ammonia recorded in Mt. Everest ice core, J. Geophys. Res., 30 107(D20), 4595, doi:10.1029/2001JD001413, 2002.

Lami, A., Guilizzoni, P., Marchetto, A., Bettinetti, R., and Smith, D. J.: Palaeolimnological evidence of environmental changes in some high altitude Himalayan lakes (Nepal), Mem. Ist. ital. Idrobiol., 57, 107-130, 1998.

Lipenkov, V., Candaudap, F., Ravoire, J., Dulac, E., and Raynaud, D.: A new device for air content measurements in polar ice, J. Glaciol., 41, 423-429, 1995.

Liu, X. and Chen, B.: Climatic warming in the Tibetan Plateau during recent decades, Int. J. Climatol., 20, 1729-1742, 2000.

Mann, M. E. and Jones, P. D.: Global surface temperatures over the past two millennia, Geophys. Res. Lett., 30(15), 1820, doi:10.1029/2003GL017814, 2003.

Martinerie, P., Raynaud, D., Etheridge, D. M., Barnola, J.-M., and Mazaudier, D.: Physical and climatic parameters which influence the air content in polar ice, Earth Planet. Sci. Lett., 112, 1-13, 1992.

Paterson, W. S. B.: The Physics of Glaciers, 3rd edition, Pergamon/Elsevier Science Ltd., 8-25, 1994.

Qin, D., Hou, S., Zhang, D., Ren, J., Kang, S., Mayewski, P. A., and Wake, C. P.: Preliminary results from the chemical records of an $80 \mathrm{~m}$ ice core recovered from the East Rongbuk Glacier, Mt. Qomolangma (Everest), Ann. Glaciol., 35, 278-284, 2002.

Richards, B. W. M., Benn, D. I., Owen, L. A., Rhodes, E. J., and Spencer, J. Q.: Timing of late Quaternary glaciations south of Mount Everest in the Khumbu Himal, Nepal, Geol. Soc. Am. Bull., 112, 1621-1632, 2000.

Röthlisberger, F. and Geyh, M. A.: Glacier variations in Himalayas and Karakorum, Z. Gletscherk. Glazialgeol., 21, 237-249, 1985.

Schwander, J., Sowers, T., Barnola, J.-M., Blunier, T., Fuchs, A., 
and Malaizé, B.: Age scale of the air in the summit ice: Implication for glacial-interglacial temperature change, J. Geophys. Res., 102(D16), 19483-19493, 1997.

Shindell, D. T., Schmidt, G. A., Miller, R. L., and Mann, M. E.: Volcanic and solar forcing of climate change during the preindustrial era, J. Clim., 16, 4094-4107, 2003.

Thompson, L. G., Yao, T., Mosley-Thompson, E., Davis, M. E., Henderson, K. A., and Lin, P.-N.: A High-Resolution Millennial Record of the South Asian Monsoon from Himalayan Ice Cores, Science, 289, 1916-1919, 2000.

Wagnon, P., Ribstein, P., Francou, B., and Pouyaud, B.: Annual cycle of energy balance of Zongo Glacier, Cordillera Real, Bolivia, J. Geophys. Res., 104(D4), 3907-3923, 1999.

$\mathrm{Xu}, \mathrm{B}$. and Yao, T.: Dasuopu ice core record of atmospheric methane over the past 2000 years, Science in China, D44(8), 689-695, 2001.
Yao, T., Duan, K., Xu, B., Wang, N., Pu, J., Kang, S., Qin, X., and Thompson, L. G.: Temperature and methane changes over the past 1000 years recorded in Dasuopu ice core, Ann. Glaciol., 35, 379-383, 2002.

Zhang, D., Qin, D., Hou, S., Kang, S., Ren, J., and Mayewski, P. A.: Climatological significance of $\delta^{18} \mathrm{O}$ record of an $80.36 \mathrm{~m}$ ice core from the East Rongbuk Glacier, Mt. Qomolangma (Everest). Sci. China, 48(2), 266-272, 2005.

Zheng, B., Xu, Q., and Shen, Y.: The relationship between climate change and quaternary glacial cycles on the Qinghai-Tibetan Plateau: review and speculation, Quat. Int., 97-98, 93-101, 2002. 